\title{
Adjustment to Pakistan among Finnish expatriates
}

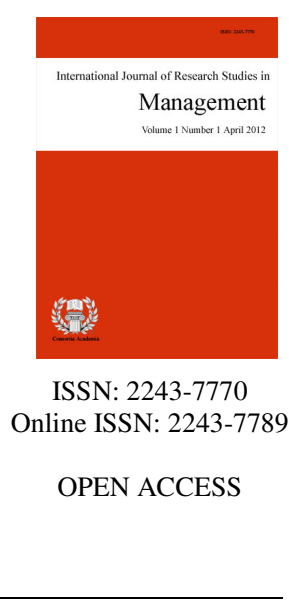

\section{Abstract}

Expatriation has become an insightful context for studying employees' adjustment to different host organisations and countries, because it contains a vast array of contradictions and tensions. This context has attracted several studies, which have studied different characteristics of the adjustment as well as processual aspects involved in it. The adjustment of self-initiated expatriates working in distant locations which are substantially different from their own - in particular the move from the developed to the developing country with very different cultural characteristics - has, however, gained less interest. To develop the current understanding about western expatriates' adjustment in this setting further, the study adapts an individual-level perspective to expatriation and uses hermeneutical approach to describe and analyse the adjustment of Finnish expatriates to Pakistan. A qualitative study was carried out; seven Finnish expatriates having expatriation experience from Pakistan were contacted and interviewed, and the qualitative content analysis method was used to analyse and interpret the generated research data. The study shows how young Finnish expatriate proactively seek overseas experiences. They are also largely motivated by altruism. Their personal ambitions to do social good for both the local community and to the host country drive for expatriation. In addition, the studied expatriates actively try to overcome the experienced cultural differences. However, the experienced organisational hierarchies, the expatriates' freedom of choice, and the gender roles influence their adjustment, both regarding to the host organisation and the country.

Keywords: adjustment; expatriation; distance; security; gender 


\section{Adjustment to Pakistan among Finnish expatriates}

\section{Introduction}

Today's global economy means that the number of expatriates is growing at a rapid pace and with greater variation than before (Selmer \& Lauring, 2012). For example, many expatriates are now sent by religious and humanitarian non-profit organisations to distant locations where they may face multiple security-related challenges while working and living abroad (Oberholster, Clarke, Bendixen, \& Dastoor, 2013). However, most studies of expatriates have concentrated on traditional organisational expatriates (OEs) working for private companies (Selmer \& Lauring, 2012). In addition to OEs, more non-traditional, self-initiated expatriates (SIEs) are actively seeking work in foreign countries, even in distant (Hemmasi \& Downes, 2013; Selmer \& Lauring, 2012) and dangerous locations (Oberholster et al., 2013). Although the number of female expatriates is increasing, women as SIEs are an under-investigated group (van den Bergh \& Du Plessis, 2012). As noted by Brewster, Bonache, Cerdin, and Suutari (2014), previous expatriation studies have been primarily concerned with white male employees from Western countries (most notably from North America) sent on international work assignments by large multinational corporations. The challenges faced by women during such foreign assignments can relate, for example, to work roles (Harris, 2004), gender discrimination, and family responsibilities (Tzeng, 2006).

Most expatriate studies have been conducted from either an organisational or an individual perspective. Organisation-level studies have concentrated on such issues as managing global talent (Minbaeva \& Collings, 2013). Individual-level studies have focused on the expatriation process, from recruitment to repatriation, as well as on adjustment during expatriation and on expatriates' motives (Brewster et al., 2014). Recent studies have explored the impact on adjustment of such factors as the cultural distance between home and host countries (Colakoglu \& Caligiuri, 2008; Hemmasi \& Downes, 2013). It has also been argued that SIEs' motives for working abroad may differ from those of OEs (Selmer \& Lauring, 2012; Suutari \& Brewster, 2000).

Previous Finnish expatriation studies have analysed such matters as the careers of expatriates (Peltonen, 1998), expectations concerning expatriates' repatriation (Suutari \& Brewster, 2003), and performance management of expatriates (Suutari \& Tahvanainen, 2002), and the experiences of Finnish expatriates in Sweden, Russia, Germany and China (Suutari, 1996; 1998). In addition, Jokinen, Suutari, and Brewster (2008) and Suutari and Brewster (2000) have studied differences between Finnish OEs and SIEs. One neglected area of research is adjustment among Finnish (female) expatriates working for organisations in regions where the security situation and culture differs greatly from their home country. The present study aims to bridge this gap, adopting an individual-level, hermeneutical approach to empirically describe and analyse the adjustment of Finnish OEs and SIEs expatriates in Pakistan. The study describes experienced differences between Finnish and Pakistan organisational cultures in terms of hierarchy, independence, and gender equality. It also demonstrates how the security situation of the host country plays a central role in adjustment, developing a fuller understanding of young, self-directed, and 'boundaryless' individuals who proactively seek new offshore job opportunities and experiences.

The rest of the paper is structured as follows. After defining the key concepts of the study, we review some theoretical aspects of the factors influencing expatriate adjustment. We then discuss our methodological choices, and present the findings of the empirical qualitative study, concluding with discussion and recommendations.

\section{Theoretical framework}

\subsection{Differences between OEs and SIES}

Traditionally, the term expatriate has been used to refer an employee who has been sent overseas by his or 
Adjustment to Pakistan among Finnish expatriates

her current employer - the so-called 'organisational expatriate' (OE). Torrington, Hall, Taylor, and Atkinson have defined these expatriates as

staff whose normal place of work is in one country, but who are sent on secondment for a period of two or three years to work overseas, usually in a relatively senior position, before returning home to their original workplace. (2011, p. 144)

On the other hand, the term self-initiated expatriate (SIE) has been used to refer to a person who is not sent by a parent organisation but is instead hired on a contractual basis (Selmer \& Lauring, 2012, p. 667). As the Finnish expatriates participating in the present study are drawn from both groups, the general term expatriate is applied to all of them.

It has been argued that traditional expatriates differ from SIEs in terms of their goals and motives (Doherty, Dickmann, \& Mills, 2011). SIEs are often seeking out new experiences and may be pursuing a desire to 'find themselves' (Inkson, Arthur, Pringle, \& Barry, 1997). They often also represent the 'boundaryless' career model, driven by individual rather than organisational purposes (Inkson et al., 1997). As compared to OEs, SIEs' motives for working abroad can also relate less to monetary gain (Tung, 1998; see also Selmer \& Lauring, 2012). For example, Doherty et al. (2011, p. 595) demonstrated that SIEs were more strongly motivated by the location and reputation of the host country while OEs were more often motivated by issues such as career advancement. Suutari and Brewster (2000) demonstrated that among Finnish expatriates, SIEs were more motivated than OEs by international aspects.

Richardson and McKenna (2002) identified four types of academic SIE: explorers, refugees, mercenaries, and architects. An explorer is driven by a desire for travel and adventure. For the refugee type, expatriation is an opportunity to escape some aspect of his or her previous life, and for the mercenary, financial incentives are the primary motive. Architect expatriates are motivated by a desire to advance their career. However, it should be noted that self-initiated expatriation is an ongoing process, and that the primary motive may change over time (Selmer \& Lauring, 2012). Oberholster et al. (2013) have also demonstrated that the motives of expatriates from developed and developing countries also differ; financial incentives were found to be less important for expatriates from developed countries as compared to those from developing countries.

\subsection{Factors influencing expatriate adjustment}

Adjustment is a complex phenomenon that has been defined in different ways (Harris, 2004; Aycan, 1997). Concepts such as adjustment, adaptation, acculturation, and assimilation are often used interchangeably in expatriation studies (Hemmasi \& Downes, 2013). Here, we use the term adjustment to convey the feelings of satisfaction and comfort experienced by expatriates (Aycan, 1997; Black, 1988). While good adjustment does not necessary precede good job performance (Holopainen \& Björkman, 2005), successful adjustment of OEs can be seen as a primary goal for the home organisation, as poor adjustment to the host country can cause negative sentiment, monetary losses, and low work motivation, as well as premature re-entry (Holopainen \& Björkman, 2005).

Previous studies have identified a number of personal, work-related, and non-work factors that influence the adjustment of expatriates. In relation to personal factors, a distinction can be drawn between 'hard' and 'soft' issues (Canhilal, Shemueli, \& Dolan, 2015). While the former refer to such matters as biographical data, technical knowledge and skills, and family adaptation, the latter relate to motivation, social skills, and cross-cultural adjustment (Canhilal et al., 2015). For international assignments, along with technical competences, 'softer' skills are seen to play an important role in job performance (Minbaeva \& Collings, 2013). In particular, cross-cultural adjustment has been identified as a key determinant of successful adjustment of expatriates (Jackson \& Manderscheid, 2015). For example, Canhilal et al. (2015) found that cross-cultural abilities most strongly accounted for successful expatriation. 
According to Aycan (1997), adjustment as acculturation can be seen to consist of psychological, sociocultural, and work dimensions. The psychological dimension refers to psychological well-being, and the sociocultural dimension relates to social and cultural functioning. The work dimension refers to effectiveness and attitude toward one's job. A low stress level and deep integration may also contribute to improved performance at work, and support from the expatriate's organisation has been found to play an important role in successful adjustment (Aycan, 1997).

Black, Mendenhall and Oddou (1991) distinguished between general, interaction, and work adjustment (see Harris, 2004). General adjustment relates to an expatriate's adjustment to the host country's culture, including climate, food, and housing. Interaction adjustment refers to interactions with host nationals. Whereas, work duties and responsibilities, as well as performance standards, are related to work adjustment (Harris, 2004). Successful adaptation involves all three of these dimensions (Jackson \& Manderscheid, 2015). Ren, Shaffer, Harrison, Fu, and Fodchuk (2014) noted that the dominant view of expatriate adjustment has been fairly 'reactive', and that a more 'proactive' perspective is needed. This proactive approach emphasises the active role of expatriates in acquiring and using their own resources in adjusting to the foreign locale. In practice, this involves such activities as getting acquainted with new people and actively sourcing new information (Ren et al., 2014).

A number of models of adjustment have focused on processual aspects. Among the best known of these is Oberg's (1960) U-curve model, which describes expatriates' adjustment over time (Friedman, Dyke, \& Murphy, 2009). The stages of adaptation are characterised as honeymoon, cultural shock, adjustment, and mastery (Friedman et al., 2009; Black \& Mendenhall, 1991). According to Black and Mendenhall (1991), in the honeymoon stage, an expatriate is often excited by the new culture. The second stage is cultural shock, characterised by confusion and anxiety about cultural differences such as values and communication norms. This leads eventually to the adjustment stage, as the expatriate learns and adjusts to local customs and norms. In the final stage of mastery, the expatriate realises that they have acquired sufficient knowledge to perform effectively in the foreign culture. In their empirical review, Black and Mendenhall (1991) found that 12 of 18 empirical studies supported the U-hypothesis. Criticism of the U-curve model relates especially to its lack of theoretical explanation of how and why expatriates proceed from one stage to another (Black \& Mendenhall, 1991).

More recently, a number of studies have focused on the significance for the adaptation process of the cultural distance between home and host countries (Hemmasi \& Downes, 2013; Jenkins \& Mockaitis, 2010). Generally speaking, cultural distance refers to differences between home and host cultures (Hemmasi \& Downes, 2013). Beyond objective differences of this kind, it has been argued that the mindset of expatriates influences the adaptation process, as in their mental image of the foreign country and the validity of this image (Jenkins \& Mockaitis, 2010).

\section{Research methodology}

\subsection{Context of the study}

Trade between Finland and Pakistan has been relatively low in recent years. In 2012, Finnish exports to Pakistan were valued at 60 million Euros, and imports from Pakistan totalled 50 million Euros (Ministry for Foreign Affairs of Finland, 2014). At the moment, only a few large Finnish companies operate in Pakistan (e.g. Stora-Enso, Vaisala, Wärtsilä), but Pakistan has attracted growing interest among Finnish companies (Ministry for Foreign Affairs of Finland, 2014). Finland has also provided humanitarian aid to Pakistan, and Finland's Foreign Ministry has provided financial support for non-governmental organisations operating in Pakistan (Ministry for Foreign Affairs of Finland, 2014).

The cultural distance between Finland and Pakistan is high. Hofstede (1984) has categorised national cultures along four cultural dimensions: (1) power distance, (2) individualism versus collectivism, (3) 
Adjustment to Pakistan among Finnish expatriates

masculinity versus feminism, and (4) uncertainty avoidance. He subsequently added two further dimensions to this model: (5) long-term versus short-term orientation and (6) indulgence versus restraint (Hofstede, Hofstede, \& Minkov, 2010). Differences between Finland and Pakistan on these dimensions are presented in Table 1.

\section{Table 1}

Differences in national culture between Finland and Pakistan

\begin{tabular}{lcc}
\hline Dimension & Finland index & Pakistan index \\
\hline Power distance & 33 & 55 \\
Individualism & 63 & 14 \\
Masculinity & 26 & 50 \\
Uncertainty avoidance & 59 & 70 \\
Long-term orientation & 38 & 50 \\
Indulgence & 57 & 0 \\
\hline
\end{tabular}

Source. The Hofstede Center, http://geert-hofstede.com/

According to Hofstede et al.'s (2010) classification, Finland scores lower than Pakistan on the power-distance dimension, indicating that Finnish employees favour a participative leadership style (Islam, 2004). Finland is also a more individualistic and feminine country, as evidenced by the value assigned to equality and well-being in working life (The Hofstede Center, http://geert-hofstede.com/finland.html). Finnish women have a long history of being active participants in working life, and Finland is considered to be among the most gender-equal countries, along with other the Nordic states of Sweden, Norway, Denmark, and Iceland. Compared to Pakistan, Finland is also more short-term oriented. In contrast, Pakistan is an Islamic country with a tradition of male dominance in working life (Ali, 2013). The uncertainty avoidance is higher in Pakistan than in Finland. On the indulgence-restraint dimension, Finland is seen to be highly indulgence-oriented while Pakistan can be seen to represent a restraint culture (The Hofstede Center, http://geert-hofstede.com/finland.html).

\subsection{Data generation and analysis}

The present approach can be described as a phenomenological hermeneutics (Lindseth \& Norberg, 2004; see Thompson, 1981 for various perspectives). We believe that the hermeneutical approach serves to elucidate expatriates' subjective perceptions and lived experiences concerning their adjustment to Pakistan, on the assumption that these lived realities can be accessed through texts that convey the participants' meanings, attitudes, and behaviours. The hermeneutical approach also enabled us to play an active role as interpreters of the empirical interview data, drawing on the researchers' pre-existing understandings of the research phenomenon.

Data were collected from seven interviews with Finnish expatriates in Pakistan, yielding 85 pages in total of transcribed text. The participating expatriates were contacted by one of the authors, who had established contacts with other Finnish expatriates in Pakistan while working in a multinational corporation there for one year. At that time, there were approximately 20 Finns working in Pakistan. The interviews were conducted in 2013, either via Skype or face-to-face, after the participants had returned to Finland. The duration of interviews varied from 40 to 80 minutes. All interviews were conducted in Finnish, recorded, and transcribed, omitting only particles like 'um' and 'you know'.

The interviews were 'emotionalist' (Silverman, 2013), in that they aimed to give the researchers an authentic insight into the experiences of SIEs and OEs in adjusting to Pakistan. Interviews were semi-structured (Eriksson \& Kovalainen, 2016), informed by one author's own experiences of working as an expatriate in Pakistan and the desire to systematically compare the information provided by interviewees. Before the interviews, participants received a preliminary questionnaire asking about their background and length of expatriation in Pakistan. The interviews covered three broad themes: adjustment, learning, and experiences related to the objectives of expatriation and how these were met. The same themes were explored with each of the interviewees, but the order and form of questions (both 'what' and 'how') varied with the course of each interview.

All of the interviewees were relatively young, ranging in age from 26 to 39; five of the seven were female. 
Salminen, H., Mattila, M., \& Jokela, J.

Only one was married. Three interviewees held a managerial position. Some worked in the non-profit sector, and others worked for traditional companies (e.g. retail and FMCG). Two of the interviewees had worked in two different organisations during their time in Pakistan. Working experiences in Pakistan varied in duration from two months to almost eight years. Two interviewees had worked there for less than four months; the rest had worked there for at least one year. The median length of expatriation was 22 months. Four expatriates were SIEs, and three were OEs.

The data were analysed using qualitative content analysis (Eriksson \& Kovalainen, 2016) guided by deduction for overall analysis and interpretation. This decision can be justified on the basis of existing theoretical knowledge about adjustment processes and factors influencing adjustment. To begin, a unit of analysis was determined-in this case, the theme. A semi-structured framework for analysis was then created, based on the existing adjustment literature. Finally, the research data were categorized into themes and sub-themes according to this framework.

As one of the authors has personal experience as an SIE in Pakistan, this pre-understanding may have affected the process of interpretation and analysis. To broaden the understanding of the research phenomenon and to mitigate the likelihood of introducing assumptions too early and overlooking contradictory results, the authors carefully reviewed previous studies related to the research phenomenon. Additionally, the context, characteristics of the interviewees, and process of interpretation and analysis were described in as much detail as possible to maximise the credibility of the analysis.

\section{Results}

\subsection{Cultural distance and organisational culture influence adjustment}

Cultural distance - All the interviewees stated that they were aware of the considerable differences between the cultures of Finland and Pakistan before moving there, and most said they had some pre-knowledge or experience of Pakistan. Three had Pakistani friends in Finland, and one had visited Pakistan prior to expatriation. However, two of the interviewees felt that their knowledge of Pakistan before their expatriation was quite weak. A few of the participants stressed the importance of their work from a social perspective, in relation to development co-operation. Previous studies have indicated that expatriates working in religious and humanitarian organisations are motivated by altruism and 'making a difference' (Oberholster et al., 2013). The participating expatriates can be classified as 'explorers' (Richardson \& McKenna, 2002) because they saw the move to Pakistan as a personal challenge that they wanted to successfully meet:

...one big motivator for the expatriation in Pakistan was that I did not know anything about the region ... I wanted to learn, to understand the customs of that region and Islam. And it felt that I learned more than I could have expected to. (Female interviewee F)

Cultural distance was especially highlighted in the context of security issues. According to the interviewees, the security situation in Pakistan varied during their expatriation. In general, they would have liked to travel more around Pakistan, and the security rules and regulations of the host organisations were perceived as impinging on their everyday lives:

It was kind of shock for me, because I am an adult person, that someone restricts where I can walk and where I can travel. As a Scandinavian and Westerner, I am very independent. It was also very hard for me to accept that there were two security guards in my house at all times .... Even though I understand that it was for my own good, I felt that my privacy was completely violated ... and every time I wanted to travel somewhere, I needed to ask permission. I was irritated by the situation that, as an adult woman, I was not allowed to make my own decisions where to travel. (Female interviewee $\mathrm{E}$ ) 
Organisational culture - The expatriates' work settings included both Western and Islamic organisational cultures. Some of the interviewees also recognised colonial antecedents that influence the culture in Pakistani organisations (Islam, 2014). Familiarity with the organisational culture and job responsibilities made the adjustment easier. Most of the participants had clearly defined job duties, which made it easier for them to understand what was expected of them:

The organisational culture was a combination of Western and Islamic values ... the historical roots that Pakistan has with the United Kingdom were in a way valued in the workplace. Because I worked in a multinational corporation, the working methods were almost completely the same. (Male interviewee $\mathrm{G}$ )

The non-governmental organisation was an international organisation, with international rules and standards concerning work. Our team was international ... I had previously worked in the same non-governmental organisation in Finland, so my knowledge and familiarity of the organisation made it easier for me to adapt. (Female interviewee C)

Adjustment to work also meant adjusting to different ways of communicating with subordinates:

The hierarchy was one of the most difficult things about the job, but in the end, I learned something about it. (Female interviewee C)

The organisational culture was totally different ... In Finland, people are not used to a situation where you cannot have a discussion with your boss or superior. We [Finns] are used to direct communication, whereas in Pakistan, people say "Yes boss, it is a great idea", and actually, they are afraid to ask for advice about how to do it in practice. (Female interviewee B)

At first, I was irritated because in Finland you are used to making plans based on the facts ... and that others keep their promises. Later on, I got used to the fact that if someone said that she or he is going to do something ... I already knew at that time that it was not going to happen. I learned that ... it is more polite to say "I'll do it", even though you won't do it, rather than refusing to do it. (Female interviewee A)

Cultural differences in the role of supervisors were discussed with Finnish expatriates who held managerial positions in their host organisations. During expatriation, they learned to be strict and to express precisely what they expected of their subordinates:

In Finnish working life ... the differences between supervisor and employee are not so clear ... you can be friends with your boss outside work ... whereas in Pakistan culture, the hierarchy is really strong. (Male interviewee D)

In Finland, it is straightforward team work, not very hierarchical, rather more like brainstorming. But there [in Pakistan], it seemed very difficult. For them [Pakistanis], it was very important that there is someone who says how things should be done, and everyone sticks to their own duty. (Female interviewee F)

In general, the most distinct challenges of work adjustment related to hierarchy, independence, and supervisory roles. Finns are used to less hierarchy, an independent working style, and a communicative relationship with supervisors; in Pakistan, they had to adapt to a more strictly defined role in a hierarchical organisation, where the roles of supervisors and subordinates are clearly expressed.

As most of the participants were female (five out of seven), work adjustment was also challenging in terms of gender issues. All the women reported some form of difficulty based on their gender, especially when working in a managerial position: 
They probably did not take me so seriously. At first, it was difficult for them...how can this young female know about anything? (Female interviewee F)

My own gender complicated my adjustment ... I encountered some prejudices in the work environment. (Female interviewee $\mathrm{E}$ )

Adjustment to Pakistan-let's put it this way ... as a man, it was rather easy. (Male interviewee G)

The female expatriates also felt they were treated differently as compared to their local counterparts. They felt that because their status as foreigners gave them an advantage over local workers, they were less negatively affected by gender issues than local female employees:

For example, it was kind of confusing that we also had Pakistani female employees, along with female expatriates. However, the local male employees were not willing to work with them in the same room or to take orders from them. (Female interviewee F)

This supports Adler's (1994) finding that female expatriates working in Asian organisations were viewed primarily as foreigners by the local managers. In other words, the perceived difference in treatment of expatriate and local female employees can be understood as a result of ethnic distance between expatriates and locals (Tzeng, 2006).

\subsection{The adjustment process}

The honeymoon phase - Those who had worked in Pakistan for six months or less experienced the adjustment as relatively easy. Their time in Pakistan flew by quickly, filled with work and new friends, and local people were found to behave politely, helping the expatriates to get acquainted with new places and customs. Their reported scepticism towards the host country engendered a 'mental state' that served as a kind of facilitator that eased the initial adjustment:

It was easy to adapt at first ... I went there with the attitude that I was prepared for the worst ... my expectations were not very high, and I had no great expectations concerning the job-rather, I went there for curiosity, for new experiences... Maybe for that reason, the adjustment went better than I expected, as I was prepared for the worst ... And then I felt that everything was fine; I had a rather nice flat, there were not many things I was afraid of ... it was not too dirty ... and I could walk alone - it did not feel it dangerous at all. (Female interviewee A)

In the U-model, presented by Oberg (1960), the first months are described as a 'honeymoon period', after which difficulties often begin to surface in the form of irritation and annoyance towards the local culture. This was confirmed by the participants in the present study.

The shock phase - Those who had worked in Pakistan for more than six months argued that they were impacted at some point by cultural shock, which lasted for a few months. Common themes related to this phase were the security situation and equality issues relating to the independence and position of women and social classes:

Then, after about a month, the classical culture shock hit me ... and I remember thinking that now I just work here, but I won't stay here the rest of my life. It was kind of difficult at first ... and the security situation was kind of stressful. (Female interviewee F)

I was not prepared for the differences between social classes ... Of course, I had heard that rich people have their own servants and so on, but somehow, I did not understand it beforehand ... that there are truly those people who are almost starving ... and then the rich people, with whom I became familiar because they were my co-workers ... somehow I felt it so unfair, even though I 
really tried to grasp that they live in a different kind of society ... and then, there were the gender roles, differences between female and male. (Female interviewee $\mathrm{A}$ )

However, the participants did not feel that they had experienced any major culture shock. One even argued that the country, culture, and language played no important role in his adjustment because he knew that he would find like-minded people:

Well, I did not experience any real cultural shock because I left with a true open mind. (Male interviewee $\mathrm{G}$ )

The phases of gradual adjustment and mastery - Cultural shock was followed by a phase of gradual adjustment. In this stage, things previously perceived as odd began to feel more natural, and problematic situations occurred less frequently:

I recall that, when I arrived there [Pakistan] at the end of July, it [adjustment] became easier near Christmas; after Christmas, it was completely different ... when I started to adapt, and I was no longer merely "an outside observer", things started to run smoother." (Female interviewee F)

It was acknowledged that deep integration (or 'mastery' (Oberg, 1960)) into the local culture would take a long time-possibly years. However, the persistent 'Finnish mentality and mind set' was thought to assist integration. Deep integration was also described as a learning process, where one's values and ways of thinking converge with those of the local culture:

It really takes a very long time before you can fully integrate into the society; I don't know whether you can ever totally integrate, because you look totally different, and everybody stares at you on the street. (Female interviewee A)

If I hadn't adapted [to Pakistan], I would have left after a year or a year and a half. But then I would have not had the experiences or learned the things that I have learned now. (Male interviewee D)

\section{Conclusions}

This paper has described and analysed the adjustment of Finnish organisational and self-initiated expatriates to Pakistan. To this end, we adopted an individual-level perspective on expatriation. The issue of adjustment was examined in a qualitative study of seven Finnish expatriates who had worked in Pakistan, applying a hermeneutical approach to elicit the participants' subjective and lived experiences. The study's main contribution to the literature on western expatriates' adjustment to culturally distant countries is to add to understanding of young, self-directed, and 'boundaryless' individuals who proactively seek new job opportunities and experiences. The study highlights self-initiation among expatriates and the issue of gender in the process of adjustment. It also aligns with those expatriation studies that identify the influence of multiple individual, organisational, and environmental factors in expatriates' adjustment.

\subsection{Managerial implications and recommendations}

Based on our findings, a first recommendation is that managers in home and host organisations should understand that expatriates vary more nowadays in terms of organisational and individual background. There is also an increasing number of mission-oriented expatriates, working in non-profit organisations, as distinct from those working in multinational companies with more profit focused mindsets (Oberholster et al., 2013). The findings confirm that, along with 'traditional' expatriates, there are those, both male and female and relatively young, who actively seek work in a variety of organisations overseas or in distant locations, and who are motivated by altruism rather than by monetary reward or career development. Their personal goals and the 
opportunity to contribute to the 'social good' of the local community and country are a source of great satisfaction and a strong motive for expatriation. These issues should be taken into account when planning and implementing expatriation.

The second recommendation concerns female expatriates. Women today are no longer only spouses of male expatriates; often, they are themselves expatriates, who travel with or without family members. In our study, a majority of study participants were young, single, female expatriates. They made an active effort to adjust to the cultural differences experienced in the host organisation and country. Given their personal characteristics, issues such as expatriate partners or work-family conflicts were not considered relevant to their adjustment. However, there were evident differences in relation to gender roles, and the participating female expatriates reported experiencing gender-related differences that affected their adjustment. They also felt that they were treated differently as compared to their local counterparts. In addition, some had difficulties in fulfilling their work roles and the expectations of their supervisors. These observations align with the view that female expatriates are more likely to experience problems when moving to countries with more traditional gender roles (Harris, 2004), and that female expatriates are judged differently than other women in the host country (Adler, 1994; Tzeng, 2006). We would therefore urge managers in both home and host organisations to pay closer attention to their female expatriate workers to help them in their adjustment process. For instance, a thorough training period before expatriation would be useful, during which potential gender-related challenges could be opened up for discussion.

A third recommendation is that both home and host organisations should properly address expatriates' security and safety issues (Hemmasi \& Downes, 2103). The findings suggest that security in the host country plays a central role in expatriates' adjustment. While the participants understood that security regulations were for their own good, they also felt that security rules restricted their independence and their efforts to explore 'real' life in the host country. Home and host organisations should make an active effort to balance restrictions and freedom through careful planning and execution of expatriation to avoid potentially dangerous situations such as kidnapping.

\subsection{Limitations and direction for future studies}

The study had a number of limitations that should be addressed in future research. First, the study relied on limited interview data, collected from Finnish expatriates who were generally young, educated, and single. There is a need to generate more qualitative data on Finnish female expatriates from different backgrounds in terms of age, education, and family. For example, future studies might usefully focus on expatriates who are married and have children, often representing 'split households' (Glen, 1983) or 'transnational families' (Lima, 2001; Tzeng, 2006). Second, a time lag between the expatriation experience and subsequent interviews may have caused memory bias (Selmer \& Lauring, 2012). In addition, two interviewees' expatriation experiences lasted for only two to four months, which probably influenced their evaluation of the adjustment process. In the future, it would be useful to conduct a large-scale quantitative study to investigate in more detail the difficulties faced by Finnish expatriates in culturally and geographically distant locations like Pakistan. A study combining both employee and organisational perspectives could deepen understanding of the challenges encountered by both parties during the expatriation process. For example, interviews with local employees and supervisors would offer a new perspective on the successful adjustment of expatriates (Brewster et al., 2014). As suggested by Salamin and Hanappi (2014), more in-depth understanding of the different career trajectories of male and female expatriates is also needed.

Acknowledgements - The authors wish to express their sincere thanks to the interviewed individuals. For financial support, the second author wishes to express her gratitude to the Paolo Foundation. 


\section{References}

Adler, N. J. (1994). Competitive frontiers: Women managing across borders. Journal of Management Development, 13(2), 24-41. http://dx.doi.org/10.1108/02621719410050237

Ali, F. (2013). A multi-level perspective on equal employment opportunity for women in Pakistan. Equality, Diversity and Inclusion: An International Journal, 32(3), 289-309. http://dx.doi.org/10.1108/EDI-12-2012-0110

Aycan, Z. (1997). Expatriate adjustment as a multifaceted phenomenon: Individual and organizational level predictors. International Journal of Human Resource Management, 8(4), 434-456. http://dx.doi.org/10.1080/095851997341540

Black, J. S. (1988). Work role transitions: a study of American expatriate managers in Japan. Journal of International Business Studies, 19(2), 277-294. http://dx.doi.org/10.1057/palgrave.jibs.8490383

Black, J. S., \& Mendenhall, M. (1991). The U-curve adjustment hypothesis revisited: A review and theoretical framework. Journal of International Business Studies, 22, 225-247. http://dx.doi.org/10.1057/palgrave.jibs.8490301

Black, J. S., Mendenhall, M., \& Oddou, G. (1991). Toward a comprehensive model of international adjustment: an integration of multiple theoretical perspectives. Academy of Management Review, 16(2), 291-317.

Brewster, C., Bonache, J., Cerdin, J. B., \& Suutari, V. (2014). Exploring expatriate outcomes. International Journal of Human Resource Management, 25(4), 1921-1937. http://dx.doi.org/10.1080/09585192.2013.870284

Canhilal, S. K., Shemueli, R. G., \& Dolan, S. (2015). Antecedent factors for success in international assignments: the case of expatriates in Peru. Journal of Global Mobility, 3(4), 378-396. http://dx.doi.org/10.1108/JGM-06-2014-0016

Colakoglu, S., \& Caligiuri, P. (2008). Cultural distance, expatriate staffing and subsidiary performance: the case of US subsidiaries of multinational corporations. International Journal of Human Resource Management, 19(2), 223-239. http://dx.doi.org/10.1080/09585190701799804

Doherty, N., Dickmann, M., \& Mills, T. (2011). Exploring the motives of company-backed and self-initiated expatriates. International Journal of Human Resource Management, 22(3), 595-611. http://dx.doi.org/10.1080/09585192.2011.543637

Erikson, P. \& Kovalainen, A. (2016). Qualitative Methods in Business Research (2nd ed.). London: SAGE.

Friedman, P-A., Dyke, L. S., \& Murphy, S. A. (2009). Expatriate adjustment from the inside out: An autoethnographic account. International Journal of Human Resource Management, 20(2), 252-268. http://dx.doi.org/10.1080/09585190802670524

Glenn, E. N. (1983). Split household, small producer and dual wage earner: an analysis of Chinese-American family strategies. Journal of Marriage and the Family, 45(1), 35-46. http://dx.doi.org/10.2307/351293

Harris, H. (2004). Global careers: Work-life issues and the adjustment of women international managers. Journal of Management Development, 23(9), 818-832. http://dx.doi.org/10.1108/02621710410558431

Hemmasi, M., \& Downes, M. (2013). Cultural distance and expatriate adjustment revisited. Journal of Global Mobility, 1(1), 72-91. http://dx.doi.org/10.1108/JGM-09-2012-0010

Hofstede, G. (1984). Culture's consequences: International differences in work-related values. Newbury Park: SAGE.

Hofstede, G., Hofstede, G. J., \& Minkov, M. (2010). Cultures and organizations: Software of the mind (3rd ed.). New York: McGraw-Hill.

Holopainen, J., \& Björkman, I. (2005). The personal characteristics of the successful expatriate. A critical review of the literature and an empirical investigation. Personnel Review, 34(1), 37-50. http://dx.doi.org/10.1108/00483480510578476

Inkson, K., Arthur, M. B., Pringle, J., \& Barry, S. (1997). Expatriate assignment versus overseas experience: contrasting models of international human resource development. Journal of World Business, 32(4), 351-368. http://dx.doi.org/10.1016/S1090-9516(97)90017-1

Islam, N. (2004). Sifarish, sycophants, power and collectivism: administrative culture in Pakistan. International 
Salminen, H., Mattila, M., \& Jokela, J.

Review of Administrative Science, 70(2), 311-330. http://dx.doi.org/10.1177/0020852304044259

Jackson, D., \& Manderscheid, S. V. (2015). A phenomenological study of Western expatriates' adjustment to Saudi Arabia. Human Resource Development International, 18(2), 131-152. http://dx.doi.org/10.1080/13678868.2015.1026552

Jenkins, E. M., \& Mockaitis, A. I. (2010). You're from where? The influence of distance factors on New Zealand expatriates' cross-cultural adjustment. International Journal of Human Resource Management, 21(15), 2694-2715. http://dx.doi.org/10.1080/09585192.2010.528653

Jokinen, T., Brewster, C., \& Suutari, V. (2008). Career capital during international work experiences: contrasting self-initiated expatriate experiences and assigned expatriation. International Journal of Human Resource Management, 19(6), 979-998. http://dx.doi.org/10.1080/09585190802051279

Lii, S-Y., \& Wong, S-Y. (2008). The antecedents of overseas adjustment and commitment of expatriates. International Journal of Human Resource Management, 19(2), 296-313. http://dx.doi.org/10.1080/09585190701799861

Lima, F. H. (2001). Transnational families: institutions of transnational social space. In L. Pries (Ed.), New transnational social spaces: International migration and transnational companies in the early twenty-first century (pp. 77-93). New York: Routledge.

Lindseth, A., \& Norberg, A. (2004). A phenomenological hermeneutical method for researching lived experience. Scandinavian Journal of Caring Sciences, 18(2), 145-153. http://dx.doi.org/10.1111/j.1471-6712.2004.00258.x

Minbaeva, D., \& Collings, D. G. (2013). Seven myths of global talent management. International Journal of Human Resource Management, 24(9), 1762-1776. http://dx.doi.org/10.1080/09585192.2013.777539

Ministry for Foreign Affairs of Finland. 2014. Information about Pakistan [Tietoa Pakistanista]. Retrieved from http://www.finlandpakistan.org/public/default.aspx?nodeid=44206\&contentlan=1\&culture=fi-FI/

Oberg, K. (1960). Cultural shock: Adjustments to new cultural environments. Practical Anthropology, 7 , 177-182.

Oberholster, A. J., Clarke, R., Bendixen, M., \& Dastoor, B. (2013). Expatriate motivation in religious and humanitarian non-profit-organizations. Journal of Global Mobility, 1(1), 7-27. http://dx.doi.org/10.1108/JGM-09-2012-0007

Peltonen, T. (1998). Narrative construction of expatriate experience and career cycle: discursive patterns in Finnish stories of international career. International Journal of Human Resource Management, 9(5), 875-892. http://dx.doi.org/10.1080/095851998340856

Ren, H., Shaffer, M. A., Harrison, D. A., Fu, C., \& Fodchuk, K. M. (2014). Reactive adjustment or proactive embedding? Multistudy, multiwave evidence for dual pathways to expatriate retention. Personnel Psychology, 67(1), 203-239. http://dx.doi.org/10.1111/peps.12034

Richardson, J., \& McKenna, S. (2002). Leaving and experiencing: why academics expatriate and how they experience expatriation. Career Development International, 7(2), 67-78. http://dx.doi.org/10.1108/13620430210421614

Salamin, X., \& Hanappi, D. (2014). Women and international assignments: A systematic literature review exploring textual data by correspondence analysis. Journal of Global Mobility, 2(3), 343-374. http://dx.doi.org/10.1108/JGM-09-2013-0058

Selmer, J., \& Lauring, J. (2012). Reasons to expatriate and work outcomes of self-initiated expatriates. Personnel Review, 41(5), 665-684. http://dx.doi.org/10.1108/00483481211249166

Silverman, D. (2013). Doing qualitative research. London: SAGE.

Suutari, V. (1996). Variation in the average leadership behaviour of managers across countries: Finnish expatriates' experiences from Germany, Sweden, France and Great Britain. International Journal of Human Resource Management, 7(3), 677-707. http://dx.doi.org/10.1080/09585199600000150

Suutari, V. (1998). Leadership behaviour in Eastern Europe: Finnish expatriates' experiences in Russia and Estonia. International Journal of Human Resource Management, 9(2), 235-258. http://dx.doi.org/10.1080/095851998341071

Suutari, V., \& Brewster, C. (2000). Making their own way: international experience through self-initiated foreign 
assignments. Journal of World Business, 35(4), 417-436.

http://dx.doi.org/10.1016/S1090-9516(00)00046-8

Suutari, V., \& Brewster, C. (2003). Repatriation: empirical evidence from a longitudinal study of careers and expectations among Finnish expatriates. International Journal of Human Resource Management, 14(7), 1132-1151. http://dx.doi.org/10.1080/0958519032000114200

Suutari, V., \& Tahvanainen, M. (2002). The antecedents of performance management among Finnish expatriates. International Journal of Human Resource Management, 13(1), 55-75.

http://dx.doi.org/10.1080/09585190110092794

The Hofstede Center. Retrieved from http://geert-hofstede.com/finland.html

Thompson, J. (1981). Critical hermeneutics. Cambridge: Cambridge University Press. http://dx.doi.org/10.1017/CBO9780511609176

Torrington, D., Hall, L., Taylor, S., \& Atkinson, C. (2011). Human Resource Management (8th ed.). Essex: Pearson.

Tung, R. L. (1998). American expatriates abroad: from neophytes to cosmopolitans. Journal of World Business, 33, 125-44. http://dx.doi.org/10.1016/S1090-9516(98)90002-5

Tzeng, R. (2006). Gender issues and family concerns for women with international careers. Female expatriates in Western multinational corporations in Taiwan. Women in Management Review, 21(5), 376-392. http://dx.doi.org/10.1108/09649420610676190

Van den Bergh, R., \& Du Pessis, Y. (2012). Highly skilled migrant women: a career development framework. Journal of Management Development, 31(2), 142-158. http://dx.doi.org/10.1108/02621711211199485 
Salminen, H., Mattila, M., \& Jokela, J. 